Колоїз Ж. В. доктор філологічних наук, професор КПІ ДВНЗ «Криворізький національний університет»

\title{
КОЛЬОРАТИВ ЧОРНИЙ У РОМАНІ ВАСИЛЯ ШКЛЯРА «ЗАЛИШЕНЕЦЬ. ЧОРНИЙ ВОРОН»
}

У статті досліджено семантику, символічне значення, авторське використання кольоратива «чорний» у романі В. Шкляра «Залишенечь. Чорний Ворон»; окреслено способи реалізачї кольоративного контрасту.

Ключові слова: кольоратив, кольоропозначення, символічне значення, атрибутивний компонент.

В статье исследованы семантика, символическое значение, авторское использование колоратива «черный» в романе В. Шкляра «Чёрный Ворон», определены способы реализачии колоративного контраста.

Ключевые слова: колоратив, колорообозначение, символическое значение, атрибутивный компонент.

The article examines the semantics, symbolic meaning, author's using of colourative black in Basyl Shklyar's novel "Zalyshenets. Chornyi Voron". The ways of realization of colourative contrast are outlined.

Key words: colourative, colour symbol, symbolic meaning, attributive component.

Провідним у сучасній мовознавчій науці є системно-функціональний підхід, що тяжіє до опису мовних одиниць з огляду на їхню здатність вступати в різноманітні типи відношень і виконувати 
відповідну функцію. Комунікативна спрямованість лінгвістики визначила пріоритети досліджень - не просто описати мовне явище як самодостатній факт, а й визначити його місце в мовленнєвій діяльності індивідів, у мові як складній знаковій системі. Такий підхід став особливо актуальним для дослідження лексики, яка, як відомо, досить важко піддається системному описові. 3-поміж лексико-семантичних полів привертає увагу й група кольоропозначень як слів, що виконують винятково важливу роль у сфері комунікації, $є$ носіями вагомого інформаційного потенціалу.

Вивчення процесів відображення кольоровідчуттів у мові розпочато ще за часів Аристотеля й здійснюється в кількох напрямках. Так, скажімо, з'ясуванню лексико-семантичних особливостей кольоропозначень присвячені фундаментальні праці Р. Алімпієвої, Н. Бахіліної, Л. Грабовської, А. Брагіної та ін.; вивченням кольоративів у психолінгвістичному аспекті займалася Р. Фрумкіна; вияв етнолінгвістичного, національно-культурного компонента кольоропозначень став предметом зацікавлення в роботах В. Клокова, І. Ковальської, І. Голубовського, С. Кулінської та ін.; на поетиці колірних символів акцентовано в наукових доробках С. Срмоленко, О. Рудь, Л. Шилунової, О. Шеховцової й ін. І хоч дослідження кольороназв у лінгвістиці має давні традиції, однак навряд чи можна вважати його вичерпним, усебічним. До того ж 3 огляду на те, що кольоративи є одним з елементів смислової структури тексту, в окремий напрямок виділяють вивчення особливостей семантико-стилістичного функціонування їх у художніх творах різних авторів (праці О. Кондрашової, М. Тростникова, І. Камалової, Л. Єгорової та ін.). І це цілком закономірно. Адже індивідуальна мовотворчість посідає особливе місце в загальній мовній картині світу, а ідіостиль того чи того письменника - яскраве свідчення еволюції мови у сферах духовного ії єства й інтелектуального гарту. До того ж відображення світу в зорових і чуттєвих образах у художньому творі відбувається багато в чому завдяки кольору, що $\epsilon$ виразником певних реальних властивостей об'єкта, опис якого 
сприяє емоційному впливові на читача, свідчить про спостережливість і кольоративну майстерність митця.

У цьому плані заслуговує на увагу мова роману В. Шкляра «Залишенець. Чорний Ворон», де «із глибин забуття виринас містична постать отамана Чорного Ворона, щуо переміг смерть...». Символічного звучання набуває не лише образ Чорного Ворона як такий, але й кольоратив чорний загалом, активно використовуваний автором, що репрезентує символічне значення, демонструє здатність вступати в семантичні відношення з елементами інших лексико-семантичних полів, отримує важливі індивідуально-авторські оцінні конотації.

Антропонім Чорний Ворон, очевидно, виник унаслідок метафоричного переосмислення усталеного атрибутивно-субстантивного словосполучення чорний ворон на основі частково зовнішньої подібності та виконуваних функцій (пор.: ворон - «великий хижий птах із блискучим чорно-синім оперенням, що живе подалі від осель (переваэнно в лісі)» [Жайворонок 2006: 115]). Через відомі причини Чорний Ворон - отаман, як і чорний ворон - птах, змушений відректися від так званої цивілізації та проживати в лісі. Звідси, відповідно, й інша назва повстанців - лісовики (пор. також: чорні хлопџі).

Постійне зіставлення (чи то дистантне, чи то контактне) образів чорного ворона - птаха і Чорного Ворона - отамана (Чорновус (він же Чорний Ворон - Ж. К.) поглянув у синє-синюще небо. I побачив на вершечку граба великого хижого птаха, такого чорного, аж синій відлиск пробігав по ньому (с. 44)) викликає в уяві читача низку асоціацій, роздумів та емоційних переживань, упливає на свідомість і почуття. Подібні образи конкретизують той чи той життєвий досвід, зорові, чуттєві та слухові враження, певною мірою узагальнюють, а подекуди і збагачують його. 3 одного боку, чорний ворон, як відомо, - нечистий птах, пов'язаний зі світом мертвих, який не користується симпатіями передусім через чорне оперення (з глибокої давнини вважається вісником смерті, що широко відбито в українському фольклорі) (Так собі міркувала Ган- 
нуся, стоячи біля причілка хати, аж поки вгледіла на вершечку акації чорного ворона. Той сидів трішки надутий $і$ сонний, але Ганнуся побачила в ньому недобру прикмету, відчула якесь лихе вімування, аж млість підкотила до горла (с. 24)). 3 іншого, - чорний ворон символізує мудрість і справедливість (згідно з повір'ям, саме воронові під силу дістати живу і мертву воду, оскільки в нього є зв'язок зі світом мертвих; саме ворон є помічником у подорожі і провісником). Пор.: На сусідньому дубі давно вже прокинувся старезний чорний ворон й одним оком сонно кліпав на че видовисько. Воронові було вже двісті сімдесят літ, проте він досі не стомився спостерігати за людськими дивачтвами і намагався ставитися до них з розумінням. Тепер він сидів на дубі, який ще міџно тримав на собі поруділе листя, вдихав теплий дух ладану, $і$ чорному воронові було тут затишно. Білий місячь-четвертак не діставав його за дубовим листом, зате добре висвічував невеличку галявину, де копошилися люди. Ворон, хоч був і сліпий на одне око, відразу впізнав i свяменика, $і$ чоловіка з довгим закандзюбленим носом - він їх бачив не вперше. Щоправда, чув погано, бо ворон, по правді сказати, був уже глухий як пень. Глухий і підсліпуватий, а проте добре бачив, шо йому треба. Наприклад, иього разу він завважив із подивом, що отець Олексій не тільки вкоротив молебень, але й не опечатав могилу...<...> Та ще чуднішою для нього буде інша причта на цій галявині, - че коли згодом сюди прийдуть інші люди, вони теліотатимуть нетутешньою мовою, чужі, рогаті, себто в рогатих шапках-будьонівках, незнайомі чорному воронові люди, прийдуть $i$ відміряють двадиять кроків на схід од старезного дуба і стануть копати, і викопають труну, відкриють віко, та замість отамана знайдуть там тільки записку, від якої можна було здуріти (с. 9).

Кольоратив чорний здебільшого зберігає в романі ті міфологічні та символічні значення, які були властиві йому і в давнину. Виступаючи подекуди засобом портретних характеристик персонажів, він виконує не лише суто номінативну функцію, а й сприяє розкриттю внутрішнього стану героїв, їх вдачі, соціальної належ- 
ності, відображає традиції та індивідуальні уподобання. Наприклад: Тоді я вхопив його за того хвоста, різко підвів з колін і повернув до себе обличчям. Нi, жодної тіні страху не було в чорних шпаринах його очей, він дивився на мене з якоюсь тихою чікавістю $i$ розумінням (с. 11); - Патаді, мальчік, не плач, успокойся, - сказала красива тьотя, дивлячись на Василинку великими чорними очима. - Ти хочеш сказать, что бандіти да сіх пор в селє? (с. 317); Здорові були! - по-нашому привітався Дибенко, який теж носив чорну, але невеличку бороду (с. 123); То були люди особливі й за натурою, $і$ за своєю подобою: невисокого зросту, але дуже кремезні, смагляві, аж чорні (молились-бо до Сончя) $і$ надто повільні, ніколи нікуди не поспішали, не метушилися, навіть розмовляли знехотя (с. 295); Угледівши Ворона, Дося скотилася з валу й побігла йому назустріч. Він ніби й не здивувався, що вона опинилася саме тут. Скочив з коня чорний, як ніч (с. 377) тощо. Щоправда, атрибутивний компонент чорний, що супроводжує субстантиви очі, борода, обличчя і т. ін., не завжди має нейтральне забарвлення (використовується в прямому значенні - «кольору сажі, вугілля, найтемніший»), здебільшого письменник використовує його, аби підкреслити безпросвітність, безрадісність, сум, занепокоєність, виснаженість і т. ін. Задля цього В. Шкляр послуговується словами зі значенням процесуальної або непроцесуальної ознаки, що виникла як ознака за дією: Від незвички лищем гуляв холодок, шкіра на щоках $і$ підборідді була значно білішою, ніж дублене чоло та обвітрені вилиці, а в запалих очах чорніла така безодня, що не хотілося дивитися в дзеркало (с. 249-250); Загородній став прощатися з козаками. Підходив до кожного, тиснув руку, його очі знов усміхалися, але усмішка та була квола й розгублена. Печать якогось фатуму застигла на його зчорнілому личі (c. 207). У такому разі акцентується на часовій протяжності, тривалості тих чи тих труднощів, незгод, нещастя тощо, і як результат - підвищуються виразність, сила впливу художнього слова на читача. 
Напруга загострюється й за рахунок уведення в контекст онімних назв із відповідним колірним компонентом: Перед Чорним шляхом, що пролягав через ліс, Ворон потяг за повід ліворуч, але Мудей став як укопаний. Став, застриг вухами, і Ворон ще раз завважив, що праве вухо коня живе - навскіс надрубане, трохи вкорочене, проте чутливе і сторожке (с. 18); Він навіть сам собі не сказав би вголос, що наступної ночі вирушає в дорогу - з наси джених лебединських місчь вони переходять ближче до Чорного лісу й Холодного Яру, туди, де його вже заждалися отамани Загородній, Гупало, Голик-Залізняк (с. 160). Вони є досить промовистими, свідчать про те, що місцини названі так неспроста, з ними асоціюється відчуття страху, небезпеки, тривоги.

Зауважимо, що кольоратив чорний - один із найвикористовуваніших у романі, що вживається в прямому значенні, як засіб власне номінації. Письменник послуговується ним не лише для означення кольору очей, волосся, обличчя, тіла і т. ін., але й великою мірою для означення кольору одягу (жіночого чи чоловічого, святкового чи буденного, звичайного чи форменого). Наприклад: Скрипаль у чорному фраку з білим нагрудником і довгими, схожими на пташиний хвіст фалдами, скидався на печальну сороку, $і$ ия несусвітня сорока, окільцьована пейсами, не грала, а малювала смичком якийсь позахмарний світ - з медовими ріками й иукровими снігами (с. 34); Вони вдвох випивали по чарчі, до столу підтюпчем дріботіла заклопотана Бениха, по-чудерначькому закутана в чорну хустину так, шо стирчали рожеві вуха, й ставила на стіл курячі тельбушки, смажені на гусячому смальиі, - страву для дорогих гостей (с. 39); Сірі насмішкуваті очі, коротка русява стрижка, а далі - не питай. Туальденорова блузка з чорною краваткою, легенька ситчева спіднияя, а нижче - тримайтеся, панове офічери! - рожеві фільдеперсові панчохи щільно облягали ноженята в черевичках на високому підборі (с. 31); На ній було приталене сіре пальто зі стоячим комірием із сивого смушку, такий же смушевий капелюшок, теплі модельні черевички і... чорні гарусові панчохи (с. 251). 
Чорний колір одягу, як відомо, традиційно пов'язують і з частиною православного духівництва, яка суворо дотримується чернечої обітниці, що так само знайшло яскраве відображення на сторінках роману. Ідеться передусім про образ юродивого Варфоломія, який жив у богадільні при Чигиринському Свято-Троїцькому монастирі. Усамітнення, деякі зовнішні та внутрішні характеристики дають змогу читачеві провести паралель між ним і чорним вороном птахом: Худющий - сама шкіра та кості - Варфоломій улітку $i$ взимку ходив у довгій чорній хламиді з накинутим на голову клобуком. Рідко хто бачив його личе, ніхто не знав його віку і вгадати не міг, бо навіть старі люди пам 'ятали Варфоломія таким, як оче зараз, - безпритульним юродивим блукальцем, віщуном, що наперед угадував лихо. Через те селяни його побоювалися, бо казали, що за ним ходить біда, що начебто він ї насилає, хоча насправдi Варфоломій нічого не насилав, він тільки вгадував наперед те, щзо мало відбутися. Здавна ж відомо, що Бог, відбираючи в чоловіка розум, іноді дарує йому за че виняткову здатність пророкувати (с. 79).

Крім того, кольоратив чорний характеризує деякі атрибути повстанського війська загалом та повстанців зокрема. Так, скажімо, лексема шлик - конусоподібний верх козацької шапки, що звисає вниз, - завжди виступає в поєднанні з відповідним прикметниковим компонентом: У тій коловерті вони загубили тільки Воронову смушеву шапку, за якою тепер він дуже шкодував, не так за самою шапкою, як за чорним шликом, на котрому було вишито два слова дівочою рукою: «Вертайсь росою» (с. 15); Той, що під '̈хав праворуч, був справжнісінький вікінг - руда, як вогонь, борода, ніби теж підпалена осінню, така ж руда шапка з чорним шликом i вкорочена вище колін шинеля (с. 259). Так само чорним було i полотно повстанського прапора: Відчайдушний опір російським окупантам чинили повстанці Холодного Яру. На їхньому чорному бойовому прапорі був напис: «Воля Украӥни або смерть» ( с. 6); Жовто-блакитний $і$ чорний - холодноярський бойовий прапор, на якому срібною заполоччю було вигаптувано: «Воля Украйни або 
смерть» (с. 73); Наступної миті Ворон дістав звідти згорток чорного полотна (с. 334). У такому разі, з одного боку, чорний колір демонструє силу, міць, з іншого, - символізує рідну землю, на захист якої і згуртувалися повстанці. Це ілюструється і відповідним атрибутивно-субстантивним словосполученням чорна земля. Пор.: Тринадиять пар очей $і$ одне Карпусеве око напружено вдивлялися в чорну розкопану землю, тринадиять сердець здригалося на кожне шпортання рискаля об тверде коріння (с. 333).

Прикметникова назва кольору стоїть здебільшого в препозиції, увиразнює денотативний простір, дає змогу виокремити колірний епітет як домінувальну ознаку в характеристиці предметів, зокрема конкретних: Аж ось почувся гуркіт моторів - «їдуть!» - $і$ до Народного дому підкотила чорна легкова машина, а за нею, підстрибуючи на бруківиі, причмихала вантажівка (с. 286). Подекуди вона набуває додаткового семантичного відтінку, як-от: «темний, темніший порівняно зі звичайним кольором» (Чорні діри вибитих вікон, навіть рами потрощені, двері зірвані із завісів, під облупленими стінами - бите скло, черепки, розвіяне пір'я (с. 40); Розсипавшись полем, щоб уникнути прииільного обстрілу, вони помчали до лісу, який виднівся удалині чорною смугою (с. 54); Чорна яма дихнула на нього застояною прохолодою (с. 88)) або «брудний, покритий брудом, нечистий» (Під ногами чавкотів мочар, а далі вже чорна твань булькотіла отруйним смородом гнилі (с. 342-343); Чорна вода смачно имокнула й проковтнула його з головою (с. 344)).

Переосмислення прямого номінативного значення розширює асоціативні похідні, утворюючи весь спектр конотацій, нових прагматичних і модально-оцінних значень. Будь-який колір сам по собі, узятий окремо, не виражає експресії, і лише за певного поєднання відповідно до сюжету, композиції, авторського задуму, контекстуального оточення, конотацій, закладених історичним досвідом, національнокультурними традиціями, він репрезентує чи то позитивне, чи то негативне забарвлення. Пор.: - Ти сам? - спитала вона. - Хіба не бачиш? Голос у нього теж був чорний. Дося все зрозуміла (с. 377). 
У романі В. Шкляра кольоратив чорний сприймається порізному, залежно від того, які категорії предметів характеризуються. Вочевидь, його семантичне та функціонально-стилістичне навантаження великою мірою залежить не лише від суб'єкта, але й від зображуваної епохи, епохи протистояння, епохи визвольної боротьби. Як відомо, «одвічна боротьба добра зі злом, справедливості з несправедливістю, постійні сочіальні протистояння окреслили відповідну функціональну роль чорного кольору» [Жайворонок 2007: 163]. Це сприяє «забарвленню» в чорний колір і деяких абстрактних понять. У новоутворених субстантивно-атрибутивних сполуках кольоратив чорний набуває кваліфікації постійного епітета, а здатність таких зворотів відтворюватися в готовому вигляді забезпечила деяким із них статус фразеологічних одиниць, як-от: Тоді я ще не знав, що настане та чорна година, коли я залишуся в лісі тільки з очим китайцем, $і$ ми з '̈̈мо з ним перму сиру ворону без солі (с. 11); Проте надія на перемогу танула, а намої армії не було й не було. Думаю, що, якби не чорна безвихідь, мало хто з повстаниів заломився б, пімов на амнестію, зрадив ліс (с. 50); I голоси їхні теж були тепер іншими, сама чорна туга співала тими голосами $i$ не про далеких запорожиів, що каралися в тяжкій неволі, а ось про цих нетяг, що сиділи за нетесаними столами (с. 75); А ще яка могла бути радість од волі, за якою чорною тінню стояла розлука? (c. 279); Хай усе йде своєю чергою без принуки, фортуна сама відбере тих, на кого зможеш покластися в найчорнішу годину (с. 282); Негоже козакові скаржитися, але наприкінці листопада для нас настали чорні часи (с. 371) (пор.: чорні часи (година) - «дуже важкі часи, сповнені неприємних клопотів, страждань, біди»).

Узагальнено-переосмисленого, фразеологічно зв'язаного значення набувають і інші атрибутивно-субстантивні словосполучення на зразок чорний список, чорний реєстр - «список осіб, приречених на розправу». Наприклад: До чорних списків відповідачів-заручників (іх ще називали десятихатниками) потрапляли найпорядніші люди (с. 70); Під більшовиџькою підозрою ходили 
чи не всі вчителі й просвітяни, а для Тіни, гадаю, достатньо було вистави на Лебединській иукроварні, щоб потрапити до чорного peєстру (c. 222).

Кольоратив чорний в аналізованому романі доволі часто контрастує $з$ іншими колірними означеннями, що виявляється на тлі не лише тексту загалом, але й у межах тих чи тих мінімальних контекстів. Зразком найтиповішого кольоративного контрасту $\epsilon$, безумовно, протиставлення чорного і білого, чорного і червоного кольорів. Ці контрасти $є$ образними навіть тоді, коли кольоративні номінації використовуються в прямому значенні: Коли вона проїздила бруківкою чентральної вулиці на білому в чорних латках жеребцеві, люди крадькома хрестилися і відверталися, бо вже всі знали про ї̈ мордовню (с. 95); Ворон помітив, щзо хлопџі в доброму гуморі, видно, таки зробили щьось путне. Правда, коней загнали до білої піни а самі нівроку, світять до нього иятками очей на чорних, як засмалені горщики, фізіономіях (с. 191). На виникнення образних ускладнень впливає естетична функція слова в художньому цілому, контекстуальне оточення: - Це ж у яких таких панів мені доведеться снідати? - спитав Чорний Ворон, зводячись на лікті у твердому дерев 'яному ліжку, трохи закороткому для його отаманського зросту. - Не у панів, а в панни. У білої панни, - знов усміхнулася сама до себе Євдося. - Кажеш, піду отак просто до білої панни? - перепитав Чорний Ворон (с. 12-13); - Звісно. Я ж колись закохалася в галантного штабс-капітана, а не в кудлатого гайдамаку. - А червоний комісар тобі не підходить? - Hi, - сказала вона. - Мені подобаються «чорні хлопці» та непроста. Тому я сажею наведу смагу на твойх щоках. Інакше хтось здогадається, що ти за птиия (с. 250). Найбільш продуктивними способами реалізації кольоративного контрасту в романі В. Шкляра є: суміжне використання прямо протилежних колірних позначень ядерних $\mathrm{i}$ периферійних одиниць; накладання кольоративних номінацій; виокремлення кольоративів на тлі антонімічних відповідників. Однак це вже питання іншої наукової праці. 
Необхідність подальшого дослідження функціонально-стилістичних можливостей кольоративів у мові художньої літератури $\epsilon$ незаперечною. Це дасть змогу простежити результати переосмислення загальномовної семантики, традиційної символіки, що виявляється через незвичне контекстуальне оточення, сприятиме з'ясуванню місця і ролі кольоративів у відображенні індивідуальної мовної картини світу.

Колір, уведений до структури художнього тексту, здатний створити певний психологічний настрій, налаштувати на відповідне сприйняття твору, продемонструвати специфіку авторського світовідчуття.

\section{БІБЛІОГРАФІЯ}

Жайворонок 2006 - Жайворонок В. Знаки української етнокультури : словник-довідник / В. Жайворонок. - К. : Довіра, 2006. - 703 с.

Жайворонок 2007 - Жайворонок В. В. Українська етнолінгвістика : нариси : навч. посібн. / В. В. Жайворонок. - К. : Довіра, 2007. - 262 с.

Шкляр 2011 - Шкляр В. М. Залишенець. Чорний Ворон : текст / В. М. Шкляр. Харків : «Клуб сімейного дозвілля», 2011. - 384 с. 